\title{
Rodeando al enemigo: colectomía derecha laparoscópica por enfermedad de Crohn estenosante y fistulizante
}

\author{
Nicolás Avellaneda ${ }^{1}$, Augusto Carrie ${ }^{1}$, Federico Veracierto ${ }^{1}$ \\ ${ }^{1}$ Centro de Educación Médica e Investigaciones Clínicas "Norberto Quirno" (CEMIC). CABA, Argentina.
}

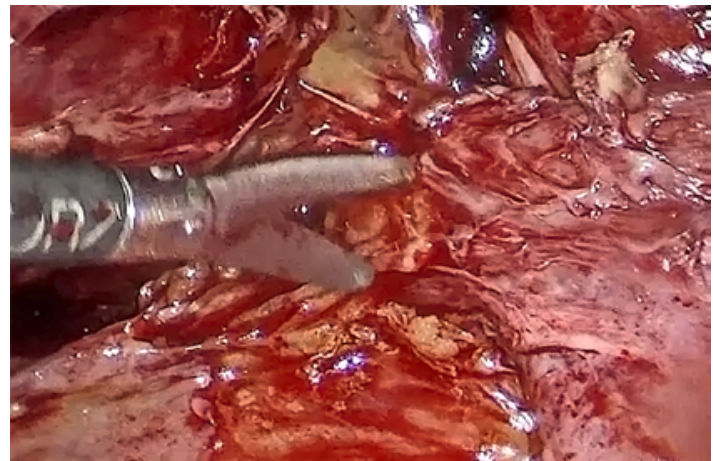

Video publicado en: https://www.youtube.com/watch?v=OG3RUe-6wTg\&has verified=1

\section{RESUMEN}

Introducción: La enfermedad de Crohn presenta una incidencia en aumento en los últimos años en los países industrializados. La afectación ileocecal es la forma de presentación más frecuente en esta patología.

En una primera instancia los pacientes pueden recibir tratamiento médico, pero un porcentaje significativo de estos puede evolucionar hacia complicaciones de la enfermedad, como estenosis o fístulas. Cuando estas se presentan, deben ser tratadas quirúrgicamente, representando un desafío para el equipo quirúrgico, ya que se trata de pacientes en mal estado general y con un gran compromiso inflamatorio a nivel abdominal que dificulta la correcta identificación de los planos anatómicos.

Descripción: Se presenta el caso de un paciente de 84 años que ingresa por guardia en nuestra institución por presentar diagnóstico de enfermedad de Crohn de 10 años de evolución, mal estado general y deterioro nutricional severo. En el examen físico se palpa tumor a nivel de flanco derecho y fosa ilíaca derecha.

Entero-TC: Íleon terminal con fístula hacia colon derecho y transverso asociado a cavidad intermedia con colección de $3 \mathrm{~cm}$ (Fig.1 y 2).

Laboratorio: glóbulos blancos: 12.000/mm3, albúmina: $1,3 \mathrm{gr} / \mathrm{dl}$.

Se decide internar al paciente e instaurar tratamiento antibiótico, medidas de sostén y nutrición parenteral total.

A las 3 semanas presenta una mejoría en los parámetros nutricionales (albúmina de 2,1 gr/dl) y en el estado general, por lo cual se programa tratamiento quirúrgico de la patología.

Se realiza una laparoscopía exploradora donde se evidencia gran tumor inflamatorio que involucra íleon terminal, colon derecho y transverso (fig. 3). Se logra la movilización completa de las estructuras mencionadas, las cuales se exteriorizan por una mini laparotomía mediana supraumbilical y se hace la resección en bloque del tumor inflamatorio, confeccionando una ileostomía terminal y abocando el colon transverso en tejido celular subcutáneo (fig. 4 y 5).

La decisión de no realizar una anastomosis primaria se basó en el mal estado nutricional del paciente. Por otro lado, abocar el colon transverso en el tejido celular subcutáneo y no exteriorizar junto a la ileostomía es una técnica que facilita el manejo de la bolsa en el postoperatorio. Sin embargo, consideramos que la alternativa de exteriorizar el colon es válida. Lo que no se debe hacer en ningún caso es abandonar el cabo distal dentro de la cavidad abdominal, dado que, en caso de abrirse el cierre (lo cual es una posibilidad viendo el estado nutricional), conllevaría complicaciones sépticas que podrían requerir una reoperación.

El paciente presenta una buena evolución postoperatoria y recibe el alta senatorial al séptimo día postoperatorio sin complicaciones.

Conclusiones: El tratamiento quirúrgico de la enfermedad de Crohn representa un desafío para el cirujano. Si es realizado por vía laparoscópica y luego de optimizar al paciente desde el punto de vista clínico y nutricional, se pueden obtener buenos resultados postoperatorios.

Palabras clave: Crohn; Estenosis; Fístula; Laparoscopía

\section{ABSTRACT}

Introduction: Crohn's disease has an increasing incidence in recent years in industrialized countries, and ileocecal involvement is the most frequent in this pathology.

Firstly, patients can receive medical treatment, but many of them can present complications of the disease such as stenosis

Los autores del trabajo declaran no tener ningún conflicto de interés.

Nicolás Avellaneda

n.avellaneda86@gmail.com

Recibido:junio de 2020. Aceptado:julio de 2020 
or fistulas. When these appear, they must be treated surgically, representing a challenge for the surgical team because these are patients in poor general condition and with a large abdominal inflammatory compromise that makes it difficult to correctly identify the anatomical planes.

Description: We present the case of an 84-year-old patient who is admitted to our institution in Emergency Service for presenting a diagnosis of Crohn's disease of 10 years of evolution, poor general condition and severe nutritional deterioration. Physical examination revealed a palpable tumor at the level of the right flank and right iliac fossa.

Entero-CT: Terminal ileum with fistula towards the right and transverse colon and intermediate cavity with a $3 \mathrm{~cm}$ collection. Laboratory: White blood cells: 12,000x10-9 / L, Albumin: $1.3 \mathrm{gr} / \mathrm{dl}$.

Decision is made to admit the patient, antibiotic treatment, support measures and total parenteral nutrition were instituted. At 3 weeks, the patient shows improvement in nutritional parameters and general condition, for which surgical treatment of the pathology is scheduled.

An exploratory laparoscopy is performed where a large inflammatory tumor involving the terminal ileum, right and transverse colon is evidenced. Complete mobilization of the aforementioned structures is achieved, which are externalized by a supraumbilical median mini laparotomy, and enbloc resection of the inflammatory tumor is made, performing a terminal ileostomy and leaving the transverse colon in subcutaneous cellular tissue.

We do not perform primary anastomosis given the compromised nutritional state of the patient. On the other hand, transverse colon is left in subcutaneous tissue because taking it out along with the ileostomy sometimes complicates the handling of the ileostomy. However, exteriorization is a possibility, but what a surgeon shouldn't do in no case is to abandon the distal end inside the abdominal cavity, because in case the closure fails (chances are real given the nutritional status) it would probably be a complication that would take a re operation.

Patient presented good postoperative evolution, receiving a sanatorial discharge on the seventh postoperative day without complications.

Conclusions: Surgical treatment of Crohn's disease represents a challenge for the surgeon. Performed laparoscopically and after optimizing the patient from a clinical and nutritional point of view, good postoperative results can be obtained.

Key words: Crohn; Stenosis; Fistula; Laparoscopy; Complication

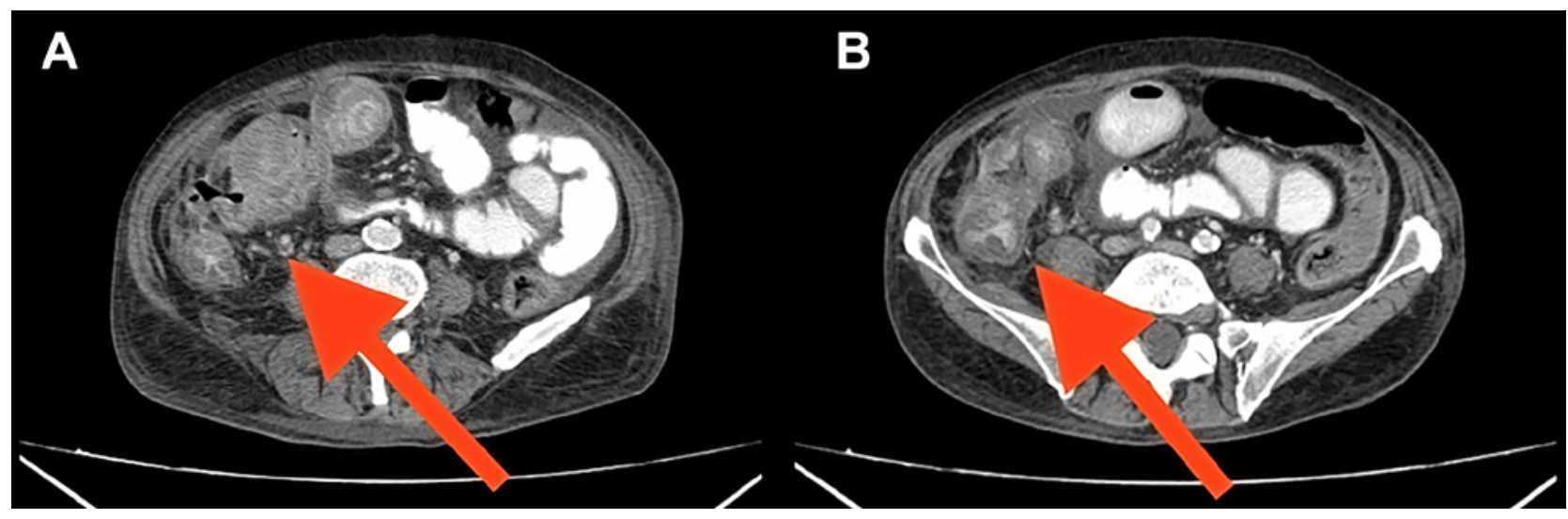

Figura 1: Entero - TAC (corte axial) evidenciando gran proceso inflamatorio y fístula entero, entérica a nivel de íleon terminal, colon derecho.
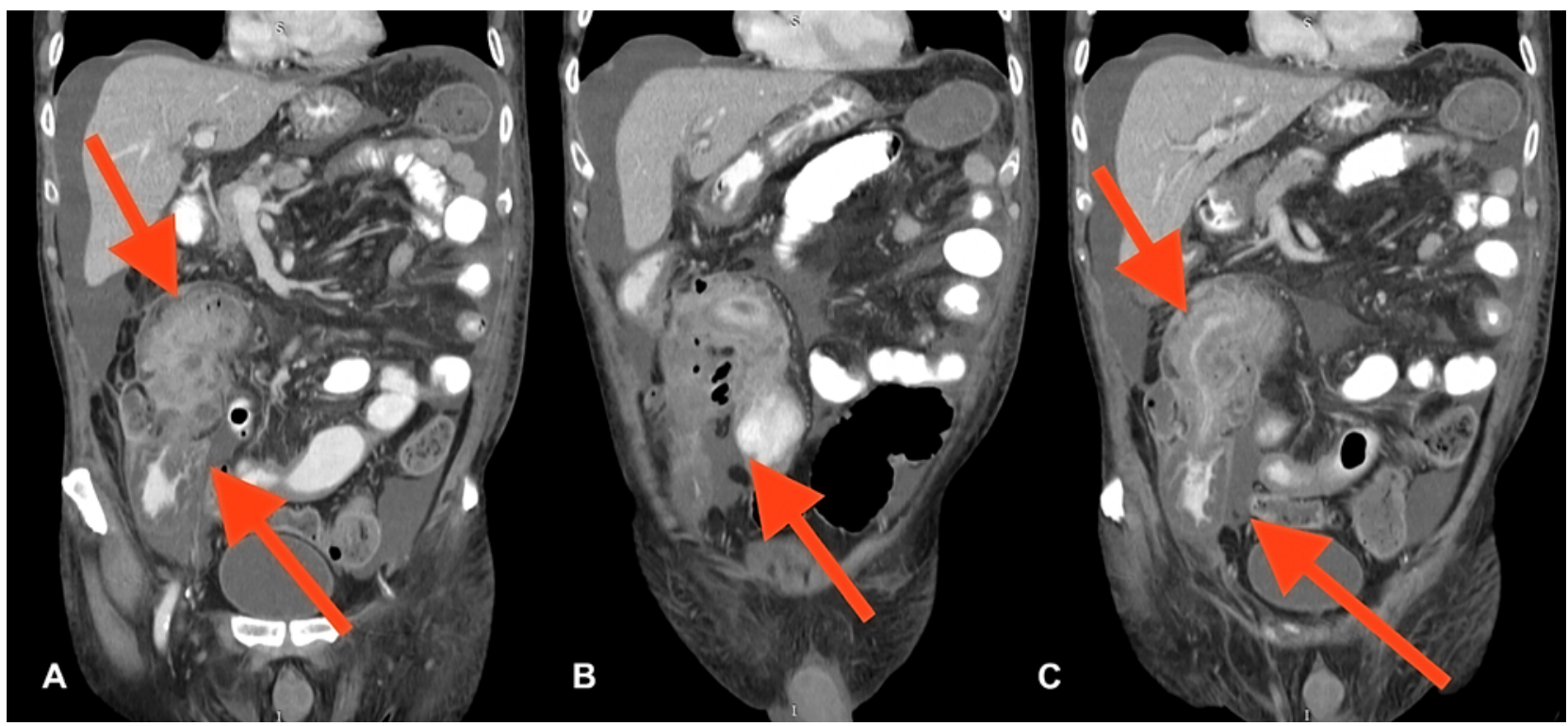

Figura 2: Entero - TAC (corte coronal) evidenciando gran proceso inflamatorio y fístula entero; entérica a nivel de íleon terminal, colon derecho. 


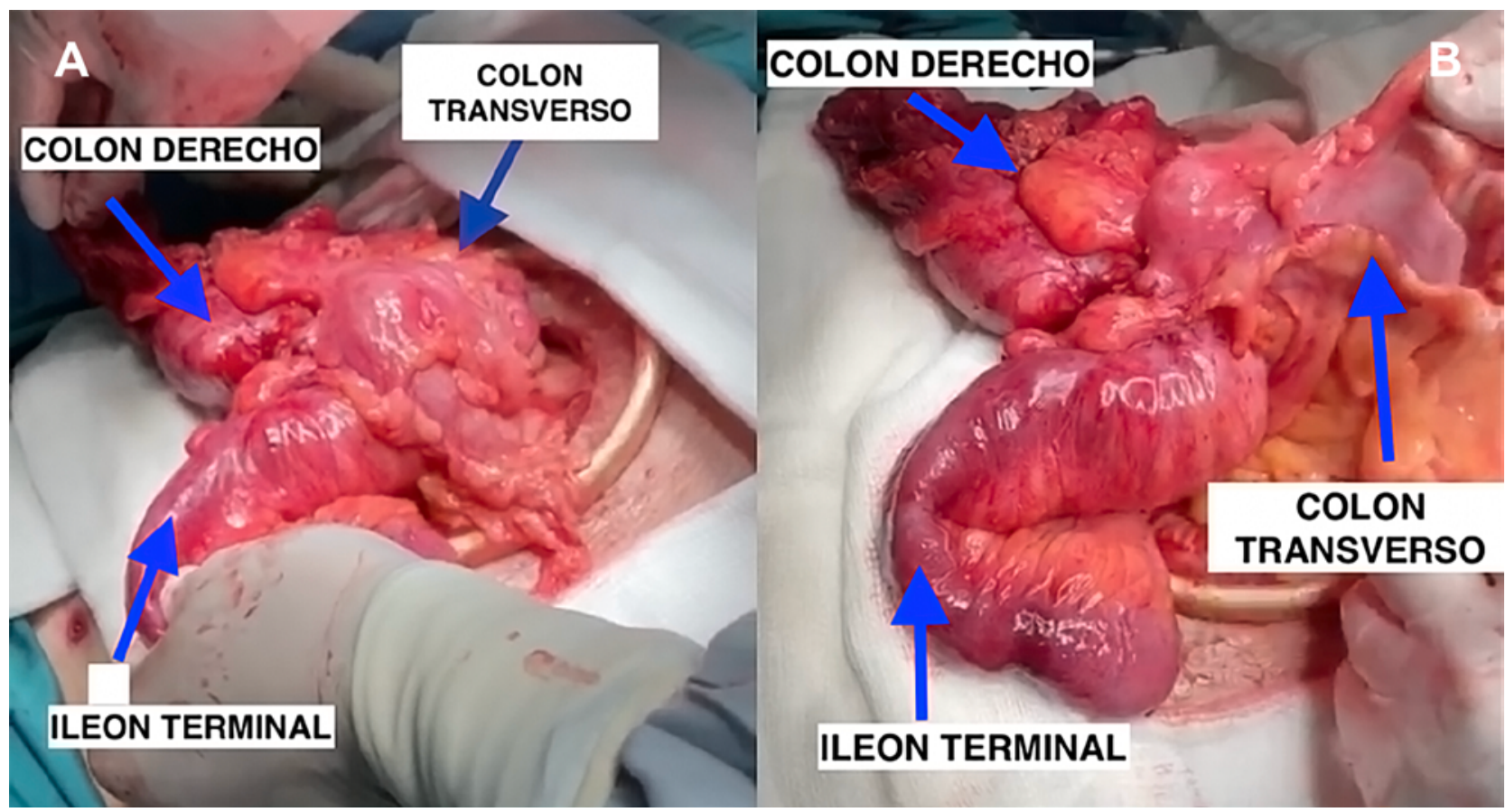

Figura 3: Hallazgo intraoperatorio: proceso inflamatorio con fístula de íleon terminal a colon derecho y colon transverso.

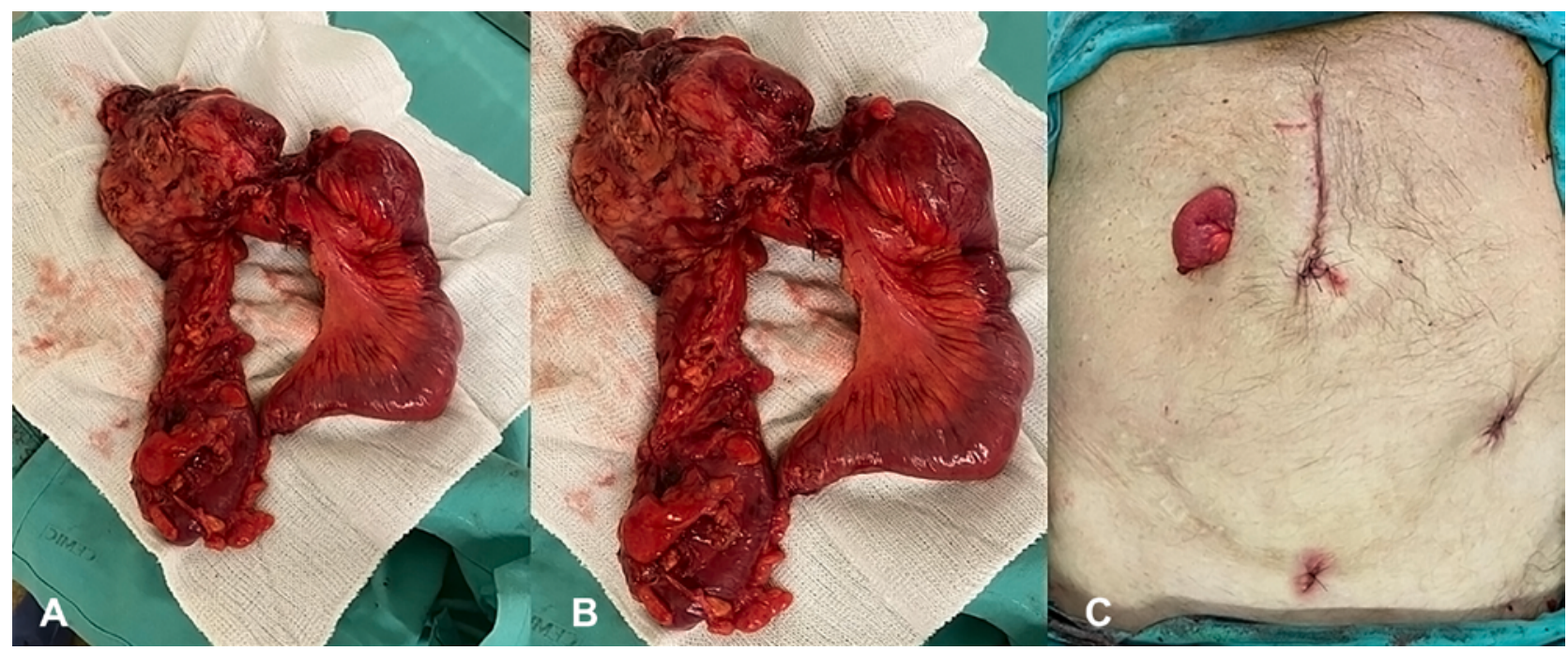

Figura 4: Pieza quirúrgica posterior a resección.

\section{COMENTARIO}

Todo paciente cursando una complicación aguda de la enfermedad de Crohn implica una situación delicada que requiere la colaboración entre los distintos profesionales actuantes para que la toma de decisiones en cuanto a qué, cuándo y cómo tratar sean correctas.

El presente video es un ejemplo de todo esto. Por un lado, frente a un paciente añoso en regular estado general y con gran compromiso inflamatorio, pudo ofrecerse una cirugía resolutiva, en el momento adecuado y con una técnica lo menos invasiva posible.

Por otro lado, el término elegido por los autores, "rodeando al enemigo", se refiere a la imposibilidad de abordar el mesocolon derecho por vía medial por la alteración de los planos anatómicos y la decisión de continuar la cirugía por vía lateral. Esto es un ejemplo de lo importante que es para un cirujano tener la capacidad de cambiar la estrategia quirúrgica en base a los hallazgos intraoperatorios.

Sebastián Guckenheimer

Hospital Pirovano. Ciudad Autónoma de Buenos Aires, Argentina. 